\title{
Perspective From a Youth Environmental Activist: Why Adults Will Listen to Youth in Politics
}

\author{
Jenna M. Hartley ${ }^{1}$, Katelyn M. Higgins ${ }^{2 *}$, M. Nils Peterson ${ }^{3}$, Kathryn T. Stevenson ${ }^{1}$ and \\ Megan W. Jackson ${ }^{4}$ \\ ${ }^{1}$ Parks, Recreation, and Tourism Management Department, North Carolina State University, Raleigh, NC, United States, \\ ${ }^{2}$ Undergraduate Environmental Sciences Program, Department of Forestry and Environmental Resources, North Carolina State \\ University, Raleigh, NC, United States, ${ }^{3}$ Fisheries, Wildlife, and Conservation Biology Program, Department of Forestry and \\ Environmental Resources, North Carolina State University, Raleigh, NC, United States, ${ }^{4}$ Environmental Inquiry Teacher, Lincoln \\ Heights Environmental Connections Magnet Elementary School, Raleigh, NC, United States
}

OPEN ACCESS

Edited by:

Sarah E. Pickard,

Université de la Sorbonne Nouvelle

Paris III, France

Reviewed by:

Benjamin Bowman, Manchester Metropolitan University,

United Kingdom

Yeojin Kim,

Central Connecticut State University,

United States

*Correspondence:

Katelyn M. Higgins

kmhiggin@ncsu.edu

Specialty section:

This article was submitted to

Political Participation,

a section of the journal

Frontiers in Political Science

Received: 01 December 2020

Accepted: 21 May 2021

Published: 10 June 2021

Citation:

Hartley JM, Higgins KM, Peterson MN Stevenson KT and Jackson MW (2021)

Perspective From a Youth Environmental Activist: Why Adults Will

Listen to Youth in Politics.

Front. Polit. Sci. 3:636583.

doi: 10.3389/fpos.2021.636583
This perspective article is divided between the account of an emerging youth political activist, Katelyn Higgins, and the subsequent collaborative research project she coordinated. After 10 years of experience in youth political action, Higgins worked with co-authors to develop a qualitative study to explore the processes underlying youth influence over local environmental policymaking. We present findings from that study to supplement her perspective. The study supported fourth and fifth grade teachers by offering a marine debris curriculum which encouraged students to share their knowledge with local community members through environmental activism events. At the first event, students aged 8-10 presented at a town hall meeting; we interviewed 16 adults in attendance. The second "event" was a series of video PSAs (Public Service Announcements) in which students from across the state of North Carolina, United States, explained the harms of marine debris. Those PSAs were emailed to local officials; we conducted follow-up interviews with two officials. Four themes emerged to characterize how adults responded to youth environmental activism: young people were inspiring; adults want to support young people; and adults view young people as able to provide leadership for local action and challenge the establishment. Youth leaders and those looking to support them should be encouraged by these results, as they suggest adults, including local public officials, consider youth voices valuable and uniquely situated to foster productive political processes for addressing marine debris. Future research should continue to explore the degree to which positive feelings expressed by adults translate to action.

Keywords: youth, civic engagement, environmental activism, youth activism, intergenerational learning, leadership, environmental education, marine debris

\section{INTRODUCTION}

Youth political activism around environmental challenges has become globally prominent. From local action in childhood hometowns to international school strikes supporting climate action led by 15-year-old Greta Thunberg, young people are taking leadership roles in politics (Marris, 2019). For many young people, environmental activism - taking steps to inspire actions among others (Arnold et al., 2009)-begins within their families or close friends (Ballantyne et al., 2001; Williams et al., 
2017; Lawson et al., 2019). For instance, young people start conversations among family and friends after learning about environmental issues in classrooms (Walker, 2016). Beyond these initial conversations, young people participate in formal activism events such as attending school strikes (García-Albacete, 2014), taking on leadership roles within organizations and communities (Zeldin et al., 2013), and both running for and winning public offices at increasing rates (Eichen, 2018).

Recent research regarding young people in political spheres suggests they can inspire change among adults; however, research is needed to understand the mechanisms of this influence, and whether the influence translates to action. Evidence suggests that adults hold positive perceptions of youth roles in formal political spheres (Thew, 2018), and that youth influence their parent's views on controversial issues despite partisan divides (Bloemraad and Trost, 2008) through intergenerational learning (Duvall and Zint, 2007; Lawson et al., 2019). These supportive parental responses, however, may operate more as platitudes stifling social and cognitive unease presented by youth activism than as precursors to actively supporting policy change (O'Brien et al., 2018). Fortunately, emerging research suggests youth activism can promote behavior and policy change in some contexts including climate change (Haynes and Tanner, 2015) and marine debris (Hartley et al., 2021). Though little research has explored the mechanisms for this process, several studies posit that young people may activate common values of wanting the best for future generations (Lawson et al., 2019), and so may be uniquely equipped to galvanize environmental action. In this paper, we contextualize descriptions of Higgins' development and experience as an environmental activist with primary qualitative research to shed light on the role of young people in political processes associated with responding to the environmental issue of marine debris. The supporting qualitative content was driven by the question "what factors contribute to positive adult responses to youth environmental activism, and what are those responses?"

\section{Personal Perspective From a Youth Environmental Activist}

Consistent with evidence demonstrating that young people can influence parents and family members (Ballantyne et al., 2001; Williams et al., 2017; Lawson et al., 2019), Higgins' first steps toward environmental activism started at home. Starting around age 10, Higgins studied energy conservation, renewable energy, and water pollution, and shared her discoveries with family members around the dinner table. Adults in her family began discussing their collective energy demands and how they could make small improvements in their home. They decided to reduce energy waste, prioritize carpooling, and prioritize environmental issues when evaluating political candidates. Many of Higgins' memories at her grandparents' house include the use of single-use plastic cups and plastic water bottles, yet after years of familial encouragement from their granddaughter, there has not been a single-use cup or water bottle in their home for over 5 years. They often call their granddaughter for her advice on environmentally responsible purchasing decisions, including their switch to hybrid vehicles.

Higgins also saw the same intergenerational learning occur among the youth she mentored. Higgins worked as a counselor at the Love A Sea Turtle (LAST) outdoor summer education camp for 8 years, where she fostered confidence and action-oriented traits among younger campers. Several years later, Higgins ran into one of her former campers and their family in the grocery store. Immediately, the mother of the former camper jokingly chided Higgins, saying, “Thanks to you, we can't use any plastic in our home anymore, we always refuse straws at restaurants, and I can no longer send my kids' school lunches with zip lock bags in them" $(K$. Higgins, personal communication, 2014). Although the nature of the conversation was convivial, the undertones were significant: Higgins realized that her influence on the LAST camper had led to subsequent intergenerational learning outcomes for that camper's parents and their associated environmental behaviors. These personal anecdotes reflect research suggesting intergenerational learning shifts familial attitudes and behaviors on environmental issues including water pollution (Uzzell, 1994), air pollution, litter (Ballantyne et al., 2001), and climate change (Lawson et al., 2019).

Higgins decided to expand her efforts into community action. At 16, she was selected as one of the 15 inaugural members of the EarthEcho International Youth Leadership Council, which galvanized her interest in more formal environmental political activism. Her youth council peers introduced state bills to require installation of solar panels on new buildings, demonstrating to Higgins that youth political participation was possible. Later that year, she traveled to Washington, DC, where she and other youth council members made Congressional visits where Senators showed interest in what the youth councilmembers had to say. These interactions solidified Higgins' belief that politicians would be willing to talk to and authentically engage with young people.

Energized by her trip to Washington, DC, Higgins began to incorporate more formal political activism into her efforts with LAST. She began by helping to develop a water quality testing classroom at a local park, where visitors could engage in an international citizen science project. Higgins promoted opening day to community leaders, the town mayor, and multiple news outlets. At that formal opening, the mayor of Greenville, North Carolina announced a proclamation ${ }^{1}$ that World Water Monitoring Day would be a city holiday each year. Fueled by this success, Higgins took another trip to Washington DC with LAST the following summer. Armed with evidence, research, talking points, and a fervor often unique to young people, she organized a meeting on seismic blasting and offshore drilling with the environmental advisor to her state Senator, Thom Tillis. At the time, President Trump was suggesting offshore drilling on the coast of North Carolina and Senator Thom Tillis had expressed support for the plans (Hotakainen, 2018). The conversation was difficult-the young people did not feel as though they were connecting with the environmental advisor to their Senator. However, despite not seeing eye-to-eye in their initial meeting, shortly thereafter, Thom Tillis reversed his stance on offshore drilling in NC (Cama, 2019).

Higgins is now leveraging her college years to learn more about the mechanisms of youth influence over adults. In one of

${ }^{1}$ Greenville, North Carolina World Water Monitoring Day Proclamation Day: https://www.facebook.com/watch/?v=1856624627704390 (accessed April 10, 2021). 
TABLE 1 | Primary questions used for interviews with informants who either attended an in-person youth-led civic engagement event or watched a youth-developed PSA video on marine debris.

1. Why are you here today?

2. What are your reactions to the event?

3. How do you perceive the roles of youth in solving environmental challenges in your community?

her first classes, she read several papers documenting intergenerational learning (e.g., Lawson et al., 2018) and began the undergraduate research project assessing efficacy of youth-led efforts to impact marine debris policy described below.

\section{METHODS: YOUTH POLITICAL ACTIVISM STUDY}

We completed a qualitative study to investigate adult responses to both in-person (e.g., presentations at town hall meetings) and virtual (e.g., video public service announcement [PSAs]) political activism delivered by fourth and fifth grade students (students aged 8-10) during 2018-2020. The activism events focused on marine debris in North Carolina, United States. Guided by the question, "what factors contribute to positive adult responses to youth environmental activism, and what are those responses," we were interested in reactions to the presentation by both voters and local officials-including changes in attitudes and/or action-as well as how the presentations influenced adults' views on youth roles in political processes. As our aim was to provide context for Higgins' experience, we chose to capture immediate, initial reactions from adults with intercept interviews. Below we summarize our research methods, on which we expand in Supplementary Appendix 1.

\section{Interview Protocol}

We used a qualitative approach (O'Leary, 2017) to explore local officials' $(n=4)$ and community adult $(n=14)$ perceptions of young people in public political spheres. One-on-one, semistructured interviews began with open-ended, primary prompts that allowed participants to drive the conversation (O’Leary, 2017) (Table 1).

\section{Student Presentations}

Students designed and carried out activism events as part of a year-long marine debris curriculum. Grounded in pedagogical strategies designed to maximize students' competence (Mitra, 2004; Zeldin, 2004), self-confidence, and agency (Bandura, 1989), the curriculum included background information on marine debris, hands-on explorations of marine debris impacts, and civic engagement activities such as creating either video PSAs or conducting in-person community events ${ }^{2}$. One in-person presentation to a Board of Commissioners in Fuquay-Varina, NC (February 2020) occurred before response to the COVID-19

${ }^{2}$ Duke University Marine Lab, Community Science Team's Marine Debris curriculum: https://sites.duke.edu/communityscience/files/2020/06/DUMLMarine-Debris-Curriculum2020.pdf (accessed April 14, 2021). pandemic forced the students to focus on PSAs. At the board meeting, the young people wanted their community officials to learn about the marine debris issue and develop community ordinances to reduce sources of marine debris. Students gave each board member a white board and marker, and requested that the board members respond with their guesses for how long it takes various items to break down in the ocean, displaying their answers to local meeting attendees $(n=75+)$. The highly erroneous responses provided the students an engaging and comedic platform from which to discuss the issue. Students designed and delivered the presentation. Students also created a logo and slogan, "A Dash More Fantastic, We Use Less Plastic," based on their town's own official tagline, "A Dash More," and then used the town hall meeting to garner support for it. Students envisioned the logo as a way for businesses to display their support for marine debris solutions with a sign or sticker in their storefront window. Through this process, the students provided concrete solutions to the marine debris issue in their own community and called on their officials and community members to take action. Subsequent follow-up activism efforts included contacting local businesses to encourage use of the logo, and other students developing 37 total PSAs across the entire state of North Carolina (see YouTube link ${ }^{3}$ ), which we directemailed to local officials. As with the in-person event, students designed and delivered the PSAs, with support from teachers. A review of video PSAs points to similar goals-to educate viewers on the issue and inspire action.

\section{Data Collection}

We recruited participants through intercept sampling at the inperson event (i.e., directly approaching town hall participants), or via email invitation for the video PSAs. We conducted 16 intercept interviews at the in-person event and two phone interviews with local officials who viewed the online PSAs. All participants were given pseudonyms.

\section{Data Analysis}

We analyzed all transcripts using NVivo software, Version 12 Pro (QSR International, 1999). Prior to conducting the interviews, we created a coding framework based on existing literature related to adult attitudes toward youth political activism (Derr et al., 2018; Payne and Hart, 2020). We shaped themes and subthemes by iterative cycles of analysis, as the authors read over the transcripts for word repetition, explored context and usage of certain concepts and words, and examined the interconnections therein (O'Leary, 2017).

${ }^{3} \mathrm{PSA}$ videos affiliated with this project: https://www.youtube.com/channel/ UCDi6GpY4b1RIEYw_H8OcXvA (accessed April 10, 2021). 


\section{FINDINGS}

Four central themes emerged around adult responses to youth activism. Informants reported that young people were inspiring, that they wanted to support young people, that they viewed young people as able to provide leadership for local action, and that young people could effectively challenge the establishment. Informants perceived young people to be change-makers and referred nearly unanimously to them as "the future." Many informants also took note of how informed, empowered, and solutions-oriented the students were, with comments such as "Young people can not only teach adults, but teach other young people lifelong habits for environmental sustainability." Even the Mayor commented publicly on the leadership and inspiration displayed by the students at the end of the event by saying to everyone in the room, "We've got to use things sensibly. I think it's a little bit deeper than just plastics. 'Where do we want our world to be 50 years from now?' ... We learned a lesson today from our young people."

\section{Youth Are Inspiring}

Young people were described as inspirational as they build hope in the future. Josh said, "If they [the young people] can bring awareness to what's going on today and make a small change, maybe that can make a big change in the future." While reflecting on the town hall event, Cassie told us, "When you're older, you forget at that age how passionate you can be about something and you can tell they really weren't just reading the script, they were really into it." Informants described young people as inspirational leaders repeatedly:

"I feel like they are going to be the leaders in environmental change, and they're doing a great job already in an elementary school."-Mike, Town Hall Event.

“It's very important because they're learning at a young age what would impact them and the environment, so I would think, definitely, they have a voice even now at this young age, and I think it's wonderful."-Brian, Town Hall Event.

"They're passionate enough about it that they are standing up here in front of a room packed full of adults that they don't know."-Jocelyn, Town Hall Event.

"This is going to be a mission for them in the future so it's awesome that they're starting now."-Alexis, Town Hall Event.

"And then they can start influencing their parents and their own [families'] purchasing to make those changes ... so I think they are [family] influencers, and then also getting involved within their communities."-Stephanie, PSA video.

"I guess just being young, you have the mindset that you want to hear what they have to say."-Maria, Town Hall Event.

\section{Adults Want to Support Youth}

Informants reported wanting to help young people because they were future leaders, and "the ones that have the ideas, they're flexible and open to being those change-makers." Informants also noted a desire to support the young activists educationally and emotionally. Brian said, "If they learn this stuff now, hopefully it'll carry on throughout their adult life." Lauren supported that idea by saying that the best thing adults can do to support young people is to, "I mean-simply-that's the best thing I can say is: continue their education." Emotional support and encouragement were also mentioned multiple times. Matt noted, "It was very important for them [the youth] to feel as if they were being heard" and went on to elaborate, "I think it was good for them to be in this venue to present that, because it made a connection to them in the future about government and [officials] being willing to listen."

\section{Youth Can Provide Leadership for Local Action}

Adults believed that young people could provide leadership for local action by being spokespeople on partisan issues. After watching the PSA videos, Katie explained, "I really do think that the voice of young people in this [politics] is so important because there's such a divide between old policymakers and legislators." Similarly, Maria described youth as being trusted messengers, saying, "I thought they did a very well-prepared job, and I probably listened to them more than I would if it was some older people up there," which Mike echoed with, "... hearing their statistics, I'll probably make a lot more effort to use reusable bags and take other steps to keep stuff out of the landfill." Similarly, young people were described as providing leadership needed for action with comments such as, "I really view young people as leaders and passionate committed leaders that clearly are informed ... and are passionate about the environment, not only for humans." Dawn described the young people as communicators doing ". . a great job of presenting some severe problems that we're faced with in the future."

Several informants applauded the students' solutions-oriented approach that included a "seal" that students designed for restaurants or local businesses to display confirming their commitment to reduce single-use plastic. "Having the symbol posted at the restaurants that they happen to be straw optional or paper straw to get the awareness [out] there" came up for multiple informants.

"I think they can have a big impact, especially the more voices that are heard from the community, not only to the elected officials, but for private businesses as consumers ... I think it can be impactful in that way because you can make a choice on a vendor or business based on some of their policies if those things are important to you."-John, Town Hall Event.

"I think that's kind of the key to changing things letting these kids know ... their voice can make changes in their small community, like the signs they're talking about at restaurants."-Jocelyn, Town Hall Event.

"They've got some of the businesses around here to recognize it as well!"-Brian, Town Hall Event. 


\section{Youth Can Challenge the Establishment}

There was an overwhelmingly positive response to the students "challenging" their Board of Commissioners in-person at the town hall event. Respondents found the white board activity informative and engaging. Informants said:

"I thought they were challenging to the board and asking good questions, and I thought it got a good response from everybody ... They did a good job making points and actually challenging the elected officials, so it was comical-I thought they did a great job."-Lauren, Town Hall Event.

"[I liked] all of the facts, and I think the questions to the commissioners themselves was very impactful because they [the commissioners] were way off-base for most of them."-Chloe, Town Hall Event.

"I like the statistics [on] how long things take to break down-that really helps to give it scale."-Mike, Town Hall Event.

"I thought it was very creative, the way they asked questions of the town council."-John, Town Hall Event.

\section{DISCUSSION}

It should perhaps come as no surprise that young people are inspirational, able to capture the emotional and educational support of adults, and can be viewed as leaders towards positive change despite their young age. The young people in our study were operating in formal adult spheres (i.e., town hall meetings and PSAs targeting community officials), but youth broadly are approaching systemic change both from within and outside of the system itself (Rickford, 2016). For instance, young people are presently standing on the frontlines with the DREAMers, March for Our Lives, the International Indigenous Youth Council, and the Black Lives Matter movements, largely driving calls for systemic change around a host of issues (Hogan, 2019). Our study provides one additional account of how youth activism can engender positive responses from adults within local political systems. Our results suggest that when young people engage in local environmental politics (e.g., town halls) or grassroots campaigns (e.g., video PSAs), adults seem prepared to respond with support, trust, and change, even if they did not immediately respond with a pledge for action.

The receptiveness of the adults in this study to youth-led environmental activism holds promise for both young people and communities. With the direct adult support of youth-led initiatives, young people may feel empowered in their communities, as the young people in this study were after playfully challenging local officials. This type of youth-led environmental activism can help youth influence their own futures (Kirshner, 2015), particularly when it inspires a nurturing response from community adults like Matt who said his efforts to "... [make] a connection to them ... about government and [officials] being willing to listen," reflected his desire to promote future civic activism among youth. Further, we found evidence that adults looked to the opinions of young people in their community for direction on how to prepare for the future and preserve it for coming generations. This is consistent with recent research that shows when young people are empowered and have high levels of agency, their concrete policy suggestions are generally well-received by adults (Thew, 2018). In short, evidence supports that young people benefit from environmental activism (Chawla and Cushing, 2007; Kirshner, 2015), and that this activism is shaping adult environmental perceptions (this study; Lawson et al., 2019; Hartley et al., 2021). This study is consistent with these findings, suggesting that meaningful civic education for young people (BrodieMcKenzie, 2020) can empower, support, and amplify the voices of young people, and help young people and adults alike move towards becoming better citizens.

Positive adult responses to activism among young people may backfire when it occurs without corresponding changes in adult behavior and policy action (Silberman, 2018). Civically engaged young people (e.g., Greta Thunberg) report feeling dismayed that transformative social change in the form of political or environmental impact is not taking shape (Payne and Hart, 2020). In fact, Thunberg herself recently expressed disappointment that her environmental initiatives did not seem to be making an impact in subsequent political action (Payne and Hart, 2020). Translating individual officials' support for young peoples' activism into policy change is challenging and faces barriers including partisan gridlock (Iyengar and Westwood, 2015). However, young people can promote officials' support for specific policies (Hartley et al., 2021), a critical step between supporting the ideas of young people and enacting policy. In this study, policy did follow the event, as the town where the students conducted their in-person civic engagement event adopted a plastic reduction policy eliminating the use of plastic bags for yard debris and looseleaf collection four months after the event (Fuquay-Varina, 2020). Like with Higgins' experience with Senator Tillis changing his stance on off-shore drilling, we cannot be sure that student presentations directly caused the policy change, but the timing is encouraging. We are hopeful that our preliminary findings from this work and future studies in this arena will solidify evidence that youth-led civic engagement and environmental activism can inspire adults to address marine debris (Hogan, 2019).

\section{LIMITATIONS AND FUTURE RESEARCH}

We acknowledge several limitations of this study related to its design and timing. First, Higgins' perspective as a youth environmental activist when she was the same age as the student presenters in this project could have impacted the interview process, as well as reading, coding, and thematic analysis of the transcripts, which we ameliorated by closely following interview protocols and iteratively collaborating on data analysis as a research team. Second, although intercept interviews capture adults' immediate reactions to hearing from youth activists, this method may have introduced some degree of social desirability bias (Leggett et al., 2003). However, youth activists have reported feeling as though they are taken less seriously due to their age, not more seriously (Prothero, 2019), 
so positive reactions to young peoples' activism among adults in this study are encouraging. Third, contextual factors related to responses to COVID-19 likely shaped our results. Though more in-person civic engagement events were planned, all but one were cancelled. Similarly, social conditions related to the pandemic likely shaped the relative importance of marine debris and the willingness to spend time reviewing PSAs about marine debris among community members and local officials alike. Additionally, considering that political engagement research is rapidly changing (Garcia-Albacere, 2014; Theocaris and Van Deth, 2017), future research should continue to explore mechanisms of youth influence on adults in other contexts, particularly identifying contexts where support for young peoples' activism translates to policy change. This research may include studies that employ more theoretically- and hypothesis-driven analyses than in this perspective piece. For instance, future studies may consider drawing on social constructivist traditions (Vygotsky, 1978) and communication research including the importance of framing and trusted messengers (Nisbet, 2009). Youth voices may resonate with adult audiences based on a frame with shared cultural understandings (Benford and Snow, 2000), such as promoting a better future for children to inherit. Similarly, future research could compare efficacy of messages from youth vs. adult messengers.

\section{CONCLUSION}

Youth leaders and those looking to support them should be encouraged by these results, as they suggest adults, including local public officials, consider youth voices valuable and uniquely situated to foster productive political processes for addressing marine debris. As history submits, and as Higgins has seen from personal experience as a young environmental activist coupled with her work as an undergraduate research assistant, young people may be the unsung leaders of the environmental policy movement. Although they cannot vote, they can and do influence their households, communities, and local governments. Empowering young people means that we do not have to wait for them to grow up to see change; they can lead us now, and voters and policy makers say they will listen. After all, our elected officials are charged with enabling the self-proclaimed ideal of "liberty and justice for all," wherein "all" includes the young people in their charge (Hogan, 2019). The time is now for all of us, but especially our local officials and communities, to start moving towards environmental solutions in which our local young people are boldly leading the way.

\section{DATA AVAILABILITY STATEMENT}

The raw data supporting the conclusion of this article will be made available by the authors, without undue reservation.

\section{ETHICS STATEMENT}

The studies involving human participants were reviewed and approved by North Carolina State University Institutional Review Board (\#12847). Written informed consent for participation was not required for this study in accordance with the national legislation and the institutional requirements.

\section{AUTHOR CONTRIBUTIONS}

All authors contributed to study design. MJ implemented research prerequisites with students, including preparation for the Fuquay-Varina town hall event. $\mathrm{JH}$ and $\mathrm{KH}$ were responsible for data collection and analysis. $\mathrm{KH}$ was responsible for transcription of all interview files. All authors contributed to data interpretation. $\mathrm{JH}$ was responsible for the initial drafting of the manuscript, with support from KH. KS and MP edited the manuscript, and all authors approve of its final form.

\section{FUNDING}

This work was made possible by a North Carolina Sea Grantfunded project. Project \#R/18-ELWD-1.

\section{ACKNOWLEDGMENTS}

The authors would like to thank North Carolina Sea Grant for funding the research project, and the NOAA Dr Nancy Foster Scholarship for funding the PhD Student at the helm of the paper (Jenna Hartley). Thank you to Dr Elizabeth A. DeMattia of the Duke University Marine Science Lab's Community Science team for conceptualizing and developing the Marine Debris Curriculum that teachers used throughout the year with their students. Thank you to Alexander Johnson (NC State University undergraduate researcher) for assisting with data collection. The authors would like to express their gratitude for the community adults and local officials for donating their time for interviews. Lastly, the authors would especially like to thank the participating teachers and students that made this project possible, all along believing and practicing one of the main tenets of the NC State University Environmental Education Lab: education is empowerment.

\section{SUPPLEMENTARY MATERIAL}

The Supplementary Material for this article can be found online at: https://www.frontiersin.org/articles/10.3389/fpos.2021.636583/ full\#supplementary-material 


\section{REFERENCES}

Arnold, H. E., Cohen, F. G., and Warner, A. (2009). Youth and Environmental Action: Perspectives of Young Environmental Leaders on Their Formative Influences. J. Environ. Educ. 40 (3), 27-36. doi:10.3200/JOEE.40.3.27-36

Ballantyne, R., Fien, J., and Packer, J. (2001). Program Effectiveness in Facilitating Intergenerational Influence in Environmental Education: Lessons from the Field. J. Environ. Edu. 32 (4), 8-15. doi:10.1080/00958960109598657

Bandura, A. (1989). Human agency in Social Cognitive Theory. Am. Psychol. 44 (9), 1175-1184. doi:10.1037/0003-066x.44.9.1175

Benford, R. D., and Snow, D. A. (2000). Framing Processes and Social Movements: An Overview and Assessment. Annu. Rev. Sociol. 26 (1), 611-639.

Bloemraad, I., and Trost, C. (2008). It's a Family Affair: Intergenerational Mobilization in the spring 2006 Protests. Am. Behav. Scientist 52 (4), 507-532. doi:10.1177/0002764208324604

Brodie-McKenzie, A. (2020). Empowering Students as Citizens: Subjectification and Civic Knowledge in Civics and Citizenship Education. J. Appl. Youth Stud. 3 (3), 209-222. doi:10.1007/s43151-020-00023-3

Cama, T. (2019). Is Thom Tillis Closing the Door on Offshore Drilling? Arlington, VA: E\&E News. Available at: https://www.eenews.net/stories/1060123505 Last (accessed April 10, 2021).

Chawla, L., and Cushing, D. F. (2007). Education for Strategic Environmental Behavior. Environ. Educ. Res. 13 (4), 437-452. doi:10.1080/13504620701581539

DeMattia, E., Quattrone, C., and Harshbarger, A. (2020). Program on Marine DebrisCommunity Science for 4th/5th Grades. Retrieved from: https://sites.duke. edu/communityscience/files/2020/06/DUML-Marine-Debris-Curriculum2020.pdf Last (accessed April 10, 2021).

Derr, V., Chawla, L., and Mintzer, M. (2018). Placemaking with Children and Youth: Participatory Practices for Planning Sustainable Communities. New York City, NY: New Village Press.

Duvall, J., and Zint, M. (2007). A Review of Research on the Effectiveness of Environmental Education in Promoting Intergenerational Learning. J. Environ. Edu. 38 (4), 14-24. doi:10.3200/JOEE.38.4.14-24

Eichen, A. (2018). Why Aren't Young People More Involved in Politics? YES! Magazine. Available at: https://www.yesmagazine.org/opinion/2018/10/10/whyarent-young-people-more-involved-in-politics/Last (accessed April 10, 2021).

Fuquay-Varina, N. C. (2020). Yard Debris and Loose Leaf Collection. Available at: https://www.fuquay-varina.org/558/Yard-Debris-and-Loose-Leaf-Collection Last (accessed April 10, 2021).

García-Albacete, G. M. (2014). Young People's Political Participation in Western EuropeContinuity or Generational Change?. Basingstoke: Palgrave Macmillan. doi:10.1057/9781137341310

Hartley, J. M., Stevenson, K. T., Peterson, M. N., DeMattia, E. A., Paliotti, S. T., and Fairbairn, T. J. (2021). Youth Can Promote marine Debris Concern and Policy Support Among Local Voters and Political Officials. Front. Polit. Sci., 3, 27. doi: $10.3389 /$ fpos.2021.662886

Haynes, K., and Tanner, T. M. (2015). Empowering Young People and Strengthening Resilience: Youth-Centred Participatory Video as a Tool for Climate Change Adaptation and Disaster Risk Reduction. Children's Geographies 13 (3), 357-371. doi:10.1080/14733285.2013.848599

Hogan, W. C. (2019). On the Freedom Side: How Five Decades of Youth Activists Have Remixed American History. Chapel Hill, NC: UNC Press Books.

Hotakainen, R. (2018). Trump Proposes Vast Expansion of Offshore Drilling. Washington DC: Science Magazine. doi:10.1126/science.aas9176

Iyengar, S., and Westwood, S. J. (2015). Fear and Loathing across Party Lines: New Evidence on Group Polarization. Am. J. Polit. Sci. 59 (3), 690-707. doi:10.1111/ajps.12152

Kirshner, B. (2015). Youth Activism in an Era of Education Inequality (Vol. 2). New York City, NY: NYU Press.

Lawson, D. F., Stevenson, K. T., Peterson, M. N., Carrier, S. J., Strnad, R. L., and Seekamp, E. (2019). Children Can foster Climate Change Concern Among Their Parents. Nat. Clim. Change 9 (6), 458. doi:10.1038/s41558-019-0463-3

Lawson, D. F., Stevenson, K. T., Peterson, M. N., Carrier, S. J., Strnad, R., and Seekamp, E. (2018). Intergenerational Learning: Are Children Key in Spurring Climate Action?. Glob. Environ. Change 53, 204-208. doi:10.1016/j.gloenvcha.2018.10.002
Leggett, C. G., Kleckner, N. S., Boyle, K. J., Dufield, J. W., and Mitchell, R. C. (2003) Social Desirability Bias in Contingent Valuation Surveys Administered through In-Person Interviews. Land Econ. 79 (4), 561-575. doi:10.2307/3147300

Marris, E. (2019). Why Young Climate Activists Have Captured the World's Attention. Nature 573, 471-472. doi:10.1038/d41586-019-02696-0

Mitra, D. L. (2004). The Significance of Students: Can Increasing" Student Voice" in Schools lead to Gains in Youth Development?. Teach. Coll. Rec. 106, 651-688. doi:10.1111/j.1467-9620.2004.00354.x

Nisbet, M. C. (2009). Communicating Climate Change: Why Frames Matter for Public Engagement. Environ. Sci. Pol. Sustain. Dev. 51 (2). 1223. doi:10.3200/ ENVT.51.2.12-23

O'Brien, K., Selboe, E., and Hayward, B. M. (2018). Exploring Youth Activism on Climate Change Dutiful, Disruptive, and Dissent, Dangerous. Ecol. Soc. 23 (3), 42. doi:10.5751/ES-10287-230342

O'Leary, Z. (2017). The Essential Guide to Doing Your Research Project. Sage.

Payne, P. G., and Hart, P. (2020). Environmental Education, Democracy, Thunberg, and XR. J. Environ. Edu. 51 (4), 263-269. doi:10.1080/00958964.2020.1744109

Prothero, A. (2019). Participate, but Know Your Place: Young Civic Activists Get Mixed Messages. Education Week. Available at: https://www.edweek.org/ leadership/participate-but-know-your place-young-civic-activists-get-mixedmessages/2019/10 Last (accessed April 10, 2021).

Qsr International (1999). Version 12 Pro. NVivo Qualitative Data Analysis Software. [Software]. Available from https://qsrinternational.com/nvivo/ nvivo-products/.

Rickford, R. (2016). Black Lives Matter: Toward a Modern Practice of Mass Struggle. New Labor Forum 25 (1), 34-42. doi:10.1177/1095796015620171

Silberman, M. (2018). Leaders-are-effecting-change Last 5 Ways New Movement Leaders Are Effecting Change. YES! Magazine. Available at: https://www.yesmagazine.org/ opinion/2018/10/17/5-ways-new-movement (accessed April 10, 2021).

Theocharis, Y., and Van Deth, J. W. (2017). Political Participation in a Changing World: Conceptual and Empirical Challenges in the Study of Citizen Engagement. New York City, NY: Routledge.

Thew, H. (2018). Youth Participation and agency in the United Nations Framework Convention on Change. Int. Environ. Agreements: Polit. L. Econ. 18 (3), 369-389. doi:10.1007/s10784-018-9392-2

Uzzell, D. (1994). Children as Catalysts of Environmental Change (Final rep.) London. England: European Commission Directorate General for Science Research and Development Joint Research Centre.

Vygotsky, L. (1978). Interaction between Learning and Development. Readings Dev. Child. 23 (3), 34-41.

Walker, C. (2016). Tomorrow's Leaders and Today's Agents of Change? Children, Sustainability Education and Environmental Governance. Child. Soc. 31 (1), 72-83. doi:10.1111/chso.12192

Williams, S., McLean, L., and Quinn, N. (2017). As the Climate Changes: Intergenerational Action-Based Learning in Relation to Flood Education. J. Environ. Educ. 48 (3), 154-171. doi:10.1080/00958964.2016.1256261

Zeldin, S., Christens, B. D., and Powers, J. L. (2013). The Psychology and Practice of Youth-Adult Partnership: Bridging Generations for Youth Development and Community Change. Am. J. Community Psychol. 51 (3-4), 385-397. doi:10. 1007/s10464-012-9558-y

Zeldin, S. (2004). Youth as Agents of Adult and Community Development: Mapping the Processes and Outcomes of Youth Engaged in Organizational Governance. Appl. Dev. Sci. 8 (2), 75-90. doi:10.1207/s1532480xads0802_2

Conflict of Interest: The authors declare that the research was conducted in the absence of any commercial or financial relationships that could be construed as a potential conflict of interest.

Copyright (c) 2021 Hartley, Higgins, Peterson, Stevenson and Jackson. This is an open-access article distributed under the terms of the Creative Commons Attribution License (CC BY). The use, distribution or reproduction in other forums is permitted, provided the original author(s) and the copyright owner(s) are credited and that the original publication in this journal is cited, in accordance with accepted academic practice. No use, distribution or reproduction is permitted which does not comply with these terms. 